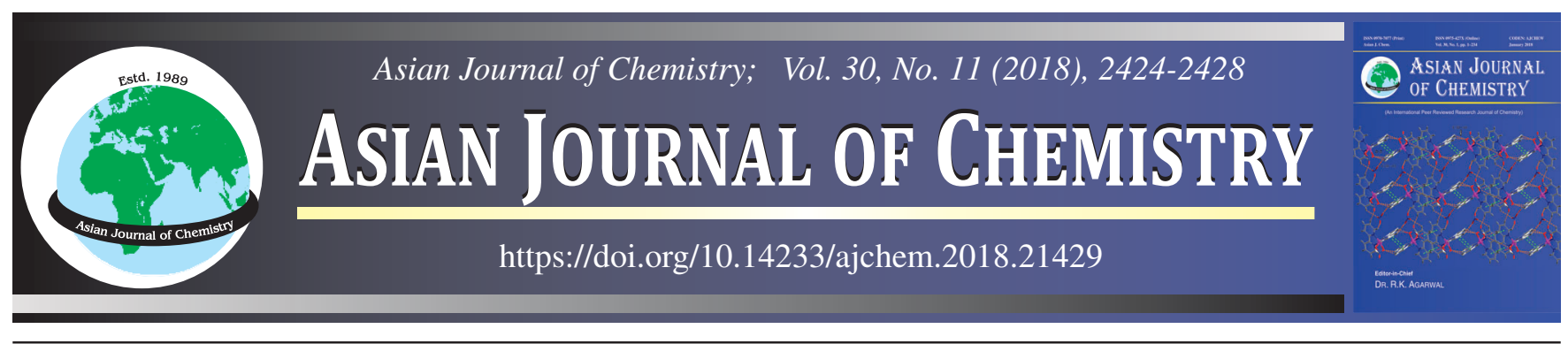

\title{
Synthesis and Chelating Behaviour of Multidentate Ligand With Some Transition Metal(II) Ions
}

Navneet Sinha, Sahdeo Kumar, Deepak Kumar, Chandra Mauleshwar Chandra, Santosh Kumar and Shivadhar Sharma*

University Department of Chemistry. Magadh University, Bodh Gaya-824 234, India

*Corresponding author: E-mail: sharma.shivadhar@gmail.com

Received: 8 May 2018;

Accepted: 30 June 2018;

Published online: 27 September 2018;

AJC-19088

| A multidentate ligand, 1-benzoyl-2-(2'-carboxylphenyl)iminopropane (BIPH) has been prepared by the condensation of 1-phenylbutane1,3-dione and anthranilic acid. This ligand has been used for chelation with $\mathrm{Co}$ (II), $\mathrm{Ni}$ (II) and $\mathrm{Zn}$ (II) metal ions as primary ligand while $\mathrm{H}_{2} \mathrm{O}$, pyridine and $\alpha$-picoline as the secondary ligands. The low value of molar conductivity of $10^{-3} \mathrm{M}$ DMF solution of complexes shows that all the complexes are non-electrolyte. The comparison of IR spectra of complexes with that of free ligand reveals that the ligand | chelates through deprotonated enolic -OH group oxygen and azomethine nitrogen and not through azomethine nitrogen and carboxylic oxygen or through carbonyl oxygen and carboxylic oxygen. On the basis of magnetic moment values and electronic spectra, octahedral symmetry has been assigned to these complexes with tetragonal distortion. Thermogravimetric analysis also confirms the tetragonal distortion with elongation along $\mathrm{z}$-axis in complexes.

| Keywords: Transition metal(II) complexes, Chelation, 1-Phenylbutane-1,3-dione, Anthranilic acid.

\section{INTRODUCTION}

If a ligand combines with the metal ions contains two or more donor groups forming one or more rings with the metals the resulting compound is called a chelate compound and the ligand itself is said to be chelating agent [1]. Metal chelates play significant role in physiological processes of biological system as they participate in the form of metalloprotein in respiratory, photosynthetic, nitrogen fixation, biosynthetic and metabolic process which are essential to the foundation of life in living being [2-4]. The function of metal chelates in physiological system could be understood in the light of chelation theory. Metal chelates play specific role, particularly in the activation of enzymes, though, the role played by the metal ion chelates in an enzymic reaction is often difficult to elucidation due to the complex nature of protein structure, model studies with relatively simple metal chelates of known structures. They generally provides important information giving the clues to the roles of the metal ions in several enzymic reactions $[5,6]$. Nucleotides as co-enzymes in enzymic reactions function only in the form of metal chelates [7]. Chelation of a biomolecules with metal ions gives some important properties to the drug, which are helpful in their biological activities. The properties of the metal chelates like dissociation constant, reduction in the polarity of the metal ion in chelates, special redox potential, electron distribution, etc. have mark effect on the solubility of drugs in lipid. It facillitates the drug action and their pharmacological transport mechanism. The low polarity of metal ion in metal chelates increases its hydrophobic character which favours it permeation through the lipid layer of microorganism, which enhances the antibacterial activities of metal chelates [8-12].

Recently considerable attention has been focussed on the chelation chemistry of Schiff bases, because of their ease of preparation, structural varieties and varied denticities [13-15]. The transition metal complexes of Schiff base ligands have a broad spectrum of applications like catalyst, magnetic materials, porous materials, luminous materials, electronic and optoelectronic devices and moudling biological process [16-22]. The development of field of bioinorganic chemistry has increased the interest in Schiff base complexes, since it has been recognized that many of these complexes may serve as models for bioinorganic important species [23]. A particular interest has been those involving higher valent metal ions since they reveals amazing molecular diversity not only in coordination geometry but in more suitable changes in the ligands [24,25]. Keeping in view the above importance of Schiff base complexes of trans-

This is an open access journal, and articles are distributed under the terms of the Creative Commons Attribution-NonCommercial 4.0 International (CC BY-NC 4.0) License, which allows others to copy and redistribute the material in any medium or format, remix, transform, and build upon the material, as long as appropriate credit is given and the new creations are licensed under the identical terms. 
ition metals, it is worthwhile to synthesize and characterize the chelates of $\mathrm{Co}(\mathrm{II}), \mathrm{Ni}$ (II) and $\mathrm{Zn}$ (II) with Schiff base derived by the condensation of 1-phenylbutane-1,3-dione and anthranilic acid.

\section{EXPERIMENTAL}

All the chemical used were of AnalaR grade and used as received. 1-Phenylbutane-1,3-dione was procured from Merck and anthranilic acid was purchased from Lupin. The Schiff base ligand 1-benzoyl-2-(2'-carboxylphenyl)iminopropane (BIPH) has been prepared by the condensation of 1-phenylbutane-1,3-dione and anthranilic acid taken in equimolar ratio in ethanolic solution by refluxing in the presence of few drops of conc. $\mathrm{H}_{2} \mathrm{SO}_{4}$ for $3.5 \mathrm{~h}$. On cooling the solution, a dull yellow solid appeared which was filtered and recrystallized in acetone where by a bright yellow crystalline solid was obtained (SchemeI). The obtained Schiff base was used for the complexation with $\mathrm{Co}(\mathrm{II}), \mathrm{Ni}(\mathrm{II})$ and $\mathrm{Zn}(\mathrm{II})$.

The elemental analyses of the ligand and its metal complexes were determined by Perkin-Elmer $2400 \mathrm{CHN}$ elemental analyser. The IR spectra of the ligand and complexes have been recorded on Perkin-Elmer FTIR spectrometer spectrum to using $\mathrm{KBr}$ disc between $4000-400 \mathrm{~cm}^{-1}$. The molar conductivity of complexes in $10^{-3} \mathrm{M}$ solution in DMF was determine using Toshniwal CL01-06 conductivity bridge. The magnetic susceptibility of complexes was determined by Gouy-balance method using mercuric tetrathiocyanatocobaltate(II) as calibrant, which were converted into magnetic moment using the expression $\mu=$ $2.828\left(\chi_{\mathrm{A}} \cdot \mathrm{T}\right)^{-1 / 2}$ B.M. The electronic spectra of the metal comp- lexes have been recorded on Shimadzu UV-visible spectrophotometer (UV-160). Thermogravimetric analysis (TGA) were recorded in static nitrogen atmosphere with heating rate of 10 ${ }^{\circ} \mathrm{C} /$ min using Perkin-Elmer Diamond TGA/DTA analyser.

\section{RESULTS AND DISCUSSION}

The physico-chemical composition of ligand as well as complexes is shown in Table-1. On the basis of percentage composition and molar conductivity the complexes have been formulated as $\left(\mathrm{ML}_{2} \mathrm{X}_{2}\right)$ where $\mathrm{M}=\mathrm{Co}(\mathrm{II}), \mathrm{Ni}(\mathrm{II})$ and $\mathrm{Zn}$ (II), while $\mathrm{L}=1$-benzoyl-2-(2'-carboxylphenyl)iminopropane (BIPH) and $\mathrm{X}=\mathrm{H}_{2} \mathrm{O}$, pyridine and $\alpha$-picoline. The molar conductivity value of complexes lies between 8.4 to $9.6 \Omega^{-1} \mathrm{~cm}^{2} \mathrm{~mol}^{-1}$ which indicates their non-electrolytic nature [26,27].

IR studies: The IR spectra of ligand and its metal complexes are very cumbersome as shown in Figs.1-4 and hence only important bands have been discussed. The broad band appearing at $3350 \mathrm{~cm}^{-1}$ is assigned to $\mathrm{H}$-bonded $\mathrm{OH}$ [28-30], which shows the existence of ligand in enolic form which is further confirmed by the absence of a band near $1760 \mathrm{~cm}^{-1}$ due to $v(\mathrm{C}=\mathrm{O})$ and appearance of a band at $1040 \mathrm{~cm}^{-1}$ due to $v(\mathrm{C}-\mathrm{O})$ and another at $1655 \mathrm{~cm}^{-1}$ due to $v(>\mathrm{C}=\mathrm{C}<)$ [31-33]. A band at $3350 \mathrm{~cm}^{-1}$ gets disappeared in all the complexes, which shows that $-\mathrm{OH}$ group has undergone deprotonation and coordination has occurred through the deprotonated oxygen. The medium band appearing at $1720 \mathrm{~cm}^{-1}$ is assigned for anthranilic acid [34,35]. This band remains almost intact in the IR spectra of complexes indicating its non-involvement in coordination. The strong band at 1640 $\mathrm{cm}^{-1}$ in the spectra of free ligand is fairly assigned to $v(\mathrm{C}=\mathrm{N})$,<smiles>CC(=O)CC(C)CCCCCC(=O)c1ccccc1</smiles>

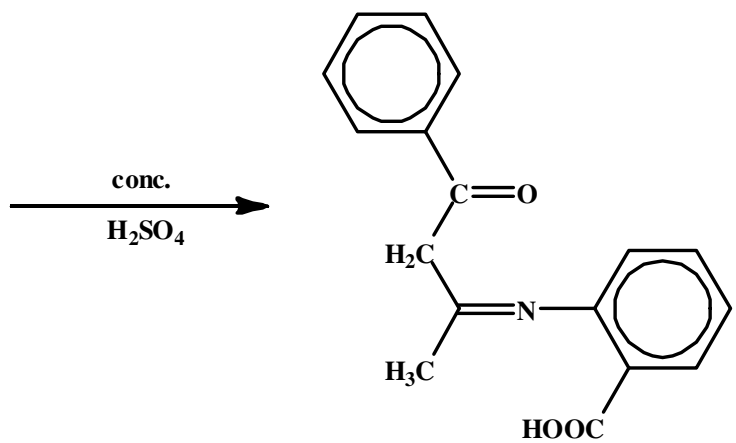

1-Benzoyl-2-(2'-carboxylphenyl)-imminopropane henceforth abbreviated as BIPH

Scheme-I

TABLE-1

ANALYTICAL, CONDUCTIVITY, MOLECULAR WEIGHT DATA OF Co(II), Ni(II) AND Zn(II) COMPLEXES OF BIP

\begin{tabular}{|c|c|c|c|c|c|c|c|c|}
\hline \multirow{2}{*}{ Compounds } & \multirow{2}{*}{ Colour } & \multirow{2}{*}{$\begin{array}{c}\text { Yield } \\
(\%)\end{array}$} & \multirow{2}{*}{$\begin{array}{l}\text { m.p. } \\
\left({ }^{\circ} \mathrm{C}\right)\end{array}$} & \multicolumn{4}{|c|}{ Elemental analysis (\%): Found (calcd.) } & \multirow{2}{*}{$\begin{array}{c}\lambda\left(\mathrm{ohm}^{-1} \mathrm{~cm}^{2}\right. \\
\left.\mathrm{mol}^{-1}\right)\end{array}$} \\
\hline & & & & $\mathrm{C}$ & $\mathrm{H}$ & $\mathrm{N}$ & $\mathrm{M}$ & \\
\hline Ligand (BIPH) & Yellow & 67 & 234 & $72.83(72.60)$ & $5.16(5.33)$ & $4.72(4.98)$ & - & - \\
\hline$\left[\mathrm{Co}(\mathrm{BIP})_{2}\left(\mathrm{H}_{2} \mathrm{O}\right)_{2}\right]$ & Dull pink & 64 & 281 & $62.80(62.30)$ & $4.67(4.88)$ & $4.20(4.30)$ & $8.86(9.00)$ & 8.5 \\
\hline$\left[\mathrm{Co}(\mathrm{BIP})_{2}(\mathrm{Py})_{2}\right]$ & Light pink & 65 & 289 & $78.41(67.95)$ & $4.53(4.90)$ & $7.00(7.20)$ & $7.24(7.60)$ & 8.6 \\
\hline$\left[\mathrm{Co}(\mathrm{BIP})_{2}(\alpha-\text { pico })_{2}\right]$ & Pink & 64 & 291 & $68.86(68.60)$ & $5.00(5.21)$ & $6.81(6.95)$ & $7.14(7.32)$ & 9.3 \\
\hline$\left[\mathrm{Ni}(\mathrm{BIP})_{2}\left(\mathrm{H}_{2} \mathrm{O}\right)_{2}\right]$ & Brilliant green & 58 & 287 & $62.57(62.38)$ & $4.62(4.89)$ & $4.08(4.28)$ & $8.56(8.86)$ & 8.4 \\
\hline$\left[\mathrm{Ni}(\mathrm{BIP})_{2}(\mathrm{Py})_{2}\right]$ & Greenish & 61 & 294 & $68.33(68.04)$ & $4.58(4.89)$ & $7.10(7.21)$ & $7.21(7.47)$ & 9.5 \\
\hline$\left[\mathrm{Ni}(\mathrm{BIP})_{2}(\alpha-\text { pico })_{2}\right]$ & Green & 60 & 297 & $68.82(68.65)$ & $5.11(5.22)$ & $6.78(6.96)$ & $7.00(7.21)$ & 9.6 \\
\hline$\left[\mathrm{Zn}(\mathrm{BIP})_{2}\left(\mathrm{H}_{2} \mathrm{O}\right)_{2}\right]$ & Dull brown & 76 & 268 & $61.97(61.72)$ & $4.38(4.84)$ & $4.16(4.23)$ & $9.62(9.83)$ & 9.2 \\
\hline$\left[\mathrm{Zn}(\mathrm{BIP})_{2}(\mathrm{Py})_{2}\right]$ & Brown & 77 & 270 & $67.72(67.43)$ & $4.46(4.85)$ & $7.00(7.15)$ & $8.16(8.30)$ & 9.4 \\
\hline$\left[\mathrm{Zn}(\mathrm{BIP})_{2}(\alpha-\text { pico })_{2}\right]$ & Brown & 77 & 274 & $68.32(68.06)$ & $4.91(5.17)$ & $6.69(6.90)$ & $7.89(8.01)$ & 8.7 \\
\hline
\end{tabular}




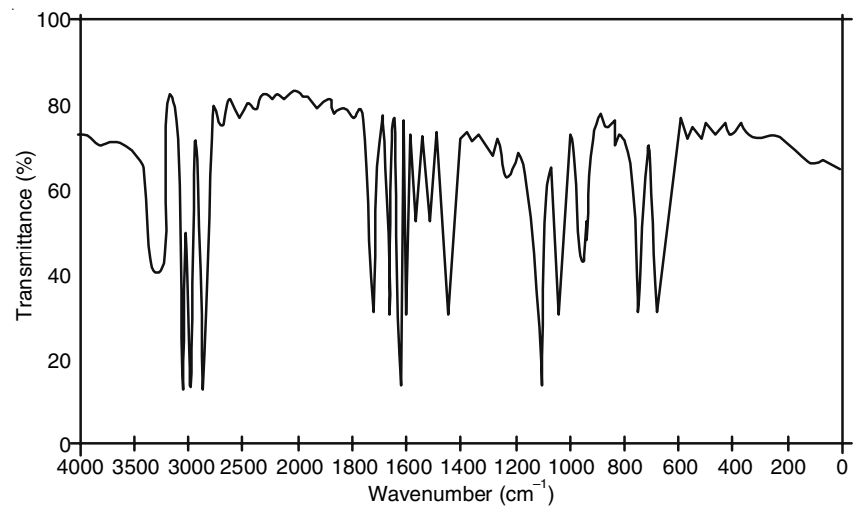

Fig. 1. IR spectra of free ligand 1-benzoyl-2(2'-carboxyl phenyl) imminopropane (BIPS)

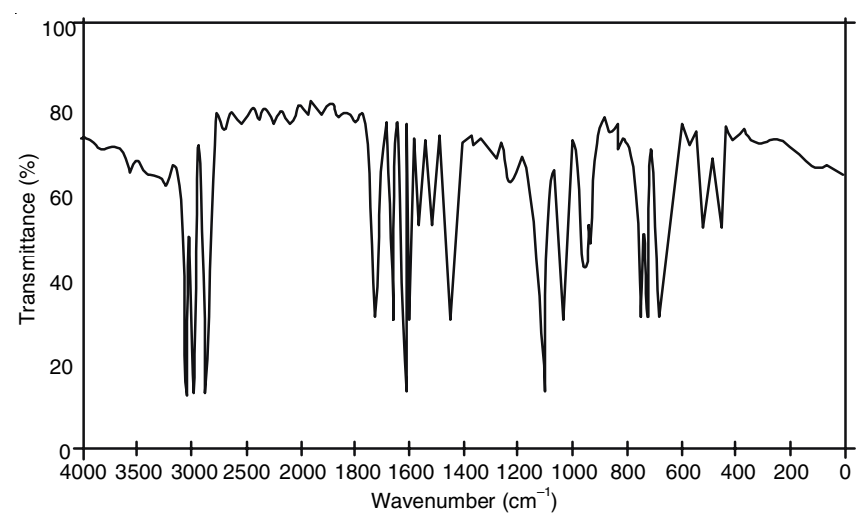

Fig. 2. IR spectra of complex $\left[\mathrm{CoL}_{2}(\mathrm{py})_{2}\right]$

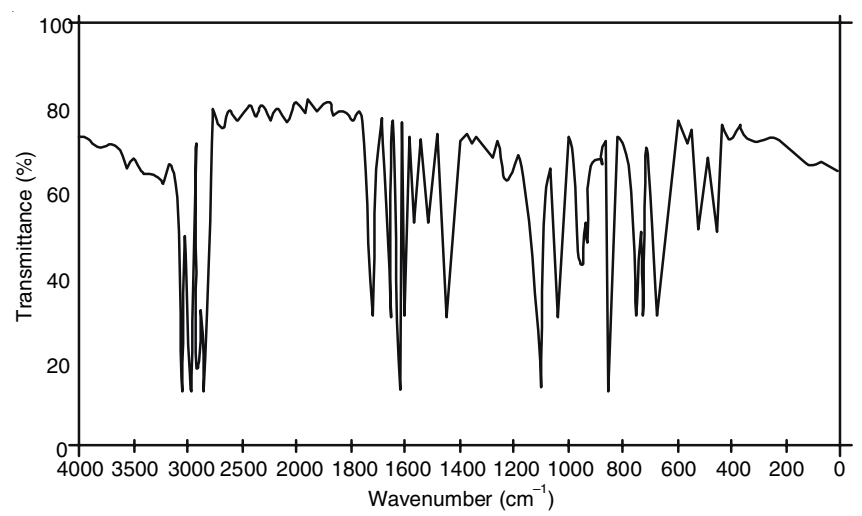

Fig. 3. IR spectra of complex $\left[\mathrm{NiL}_{2}\left(\mathrm{H}_{2} \mathrm{O}\right)_{2}\right]$

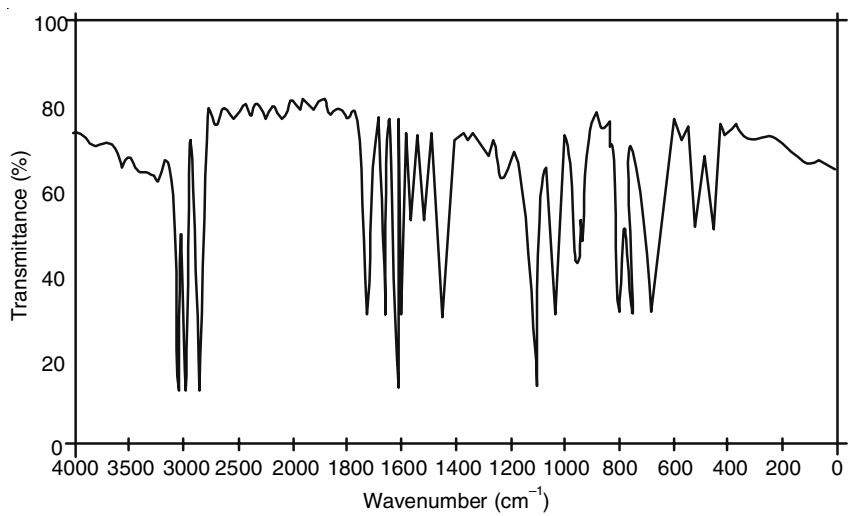

Fig. 4. IR spectra of complex $\left[\mathrm{ZnL}_{2}(\alpha \text {-pico })_{2}\right]$

azomethine group stretching vibration [36,37]. In the spectra of all the metal complexes, this band gets shifted to 1615-
$1605 \mathrm{~cm}^{-1}$ which shows azomethine nitrogen is involved in coordination to metal ion $[38,39]$. The coordination through deprotonated oxygen and azomethine nitrogen is further confirmed by the appearance of two new bands in the far infrared region of IR spectra of complexes. The new band at 515-510 $\mathrm{cm}^{-1}$ is assigned $v(\mathrm{M}-\mathrm{O})$ while other at $450-445 \mathrm{~cm}^{-1}$ is assigned to $v(\mathrm{M}-\mathrm{N})$ vibration $[40,41]$. The new broad band appearing at $2910 \mathrm{~cm}^{-1}$ with a strong band at $850 \mathrm{~cm}^{-1}$ is the signature of presence of coordinated $\mathrm{H}_{2} \mathrm{O}$ in some complexes [42]. The appearance of new bands at 750 and $800 \mathrm{~cm}^{-1}$ suggest the presence of coordinated pyridine and $\alpha$-picoline, respectively $[43,44]$ in coordination sphere of these complexes.

Magnetic moment and electronic spectra: Cobalt(II) complexes records magnetic moment 5.1-5.2 B.M. and their electronic spectra display three bands due to spin-allowed transitions ${ }^{4} \mathrm{~T}_{1 \mathrm{~g}}(\mathrm{~F}) \rightarrow{ }^{4} \mathrm{~T}_{2 \mathrm{~g}}\left(v_{1}\right),{ }^{4} \mathrm{~T}_{1 \mathrm{~g}} \rightarrow{ }_{4} \mathrm{~A}_{2 \mathrm{~g}}\left(\mathrm{~V}_{2}\right)$ and ${ }^{4} \mathrm{~T}_{1 \mathrm{~g}} \rightarrow{ }^{4} \mathrm{~T}_{1 \mathrm{~g}}(\mathrm{P})\left(\mathrm{V}_{3}\right)$. The value of $v_{2} / v_{1}=2.13-2.34$ correspond to $10 \mathrm{Dq}$ values 9354.6, 9446.2 and $9365 \mathrm{~cm}^{-1}$. The value of Racah parameter B decreases from $971 \mathrm{~cm}^{-1}$ in free $\mathrm{Co}$ (II) ion to $780-748 \mathrm{~cm}^{-1}$ in complexes. These crystal field parameter values undoubtedly indicate the octahedral symmetry of $\mathrm{Co}$ (II) complexes [4547]. The magnetic moment of $\mathrm{Ni}$ (II) complexes has been found 3.0-3.1 B.M., which is slightly higher than two unpaired electrons of $d^{8}$-system which may be due to spin-orbit coupling effect [48]. The electronic spectra of $\mathrm{Ni}(\mathrm{II})$ complexes display four bands which may be assigned to ${ }^{3} \mathrm{~B}_{1 \mathrm{~g}} \rightarrow{ }^{3} \mathrm{E}_{\mathrm{g}}(\mathrm{a}),{ }^{3} \mathrm{~B}_{1 \mathrm{~g}} \rightarrow{ }^{3} \mathrm{E}_{2 \mathrm{~g}}$ (a), ${ }^{3} \mathrm{~B}_{1 \mathrm{~g}} \rightarrow{ }^{3} \mathrm{~A}_{2 \mathrm{~g}}$ and ${ }^{3} \mathrm{~B}_{1 \mathrm{~g}} \rightarrow{ }^{3} \mathrm{E}_{\mathrm{g}}$ (b) [49,50]. On the basis of spectral bands the various crystal field parameters have been derived and their values are given in Table-2.

\section{TABLE-2}

VALUES OF DIFFERENT CRYSTAL FIELD PARAMETER OF Ni(II) COMPLEXES $\left(\mathrm{cm}^{-1}\right)$

\begin{tabular}{lcccc}
\hline \multicolumn{1}{c}{ Complexes } & $\mathrm{Dq}_{(\mathrm{xy})}$ & $\mathrm{Dq}_{(\mathrm{z})}$ & $\mathrm{D}_{\mathrm{S}}$ & $\mathrm{D}_{\mathrm{t}}$ \\
\hline$\left[\mathrm{Ni}(\mathrm{BIP})_{2}\left(\mathrm{H}_{2} \mathrm{O}\right)_{2}\right]$ & 1177.0 & 772.0 & 321.54 & 231.42 \\
{$\left[\mathrm{Ni}(\mathrm{BIP})_{2}(\mathrm{Py})_{2}\right]$} & 1176.0 & 774.0 & 322.85 & 229.71 \\
{$\left[\mathrm{Ni}(\mathrm{BIP})_{2}(\alpha-\mathrm{pico})_{2}\right]$} & 1172.5 & 771.5 & 321.07 & 229.14 \\
\hline
\end{tabular}

From the value of $D_{t}$, it is obvious that there is definite deviation from octahedral symmetry. The less value of $\mathrm{Dq}_{(\mathrm{z})}$ indicates tetragonal elongation along z-axis [51,52]. Zn(II) complexes are diamagnetic and exhibited no band in their electronic spectra. However, on the basis of microanalytical data the complexes found to be six coordinated, for which octahedral symmetry is the most preferred symmetry [53-55].

Thermogravimetric studies: The thermogram of the synthesized complex $\left[\mathrm{ML}_{2}\left(\mathrm{H}_{2} \mathrm{O}\right)_{2}\right]$ doesn't show any considerable weight loss up to $145^{\circ} \mathrm{C}$. The first step decomposition of complexes with weight loss of 5.35 to $5.55 \%$ (calculated value 5.44-5.50\%) starts at $145^{\circ} \mathrm{C}$ and completes at $200{ }^{\circ} \mathrm{C}$ due to loss of two coordinated water molecules from the coordination sphere. It confirms the presence of two coordinated water molecules in the complexes [56]. The second decomposition was found to have occurred between $260^{\circ} \mathrm{C}$ to $390^{\circ} \mathrm{C}$ corresponds to weight loss of 31.38 to $31.85 \%$ (calculated value 31.47 to $31.98 \%$ ) due to loss of $\mathrm{C}_{13} \mathrm{H}_{10} \mathrm{O}_{2}$ moiety. The third and last decomposition occurs between $445^{\circ} \mathrm{C}$ to $560^{\circ} \mathrm{C}$ correspond to weight loss of 18.9 to $19.35 \%$ (calculated value 19.0 to $19.47 \%$ ) due to loss of the remaining part of the ligand. 
The complexes finally convert into a constant composition of metal oxides above $600^{\circ} \mathrm{C}$ (Fig. 5).

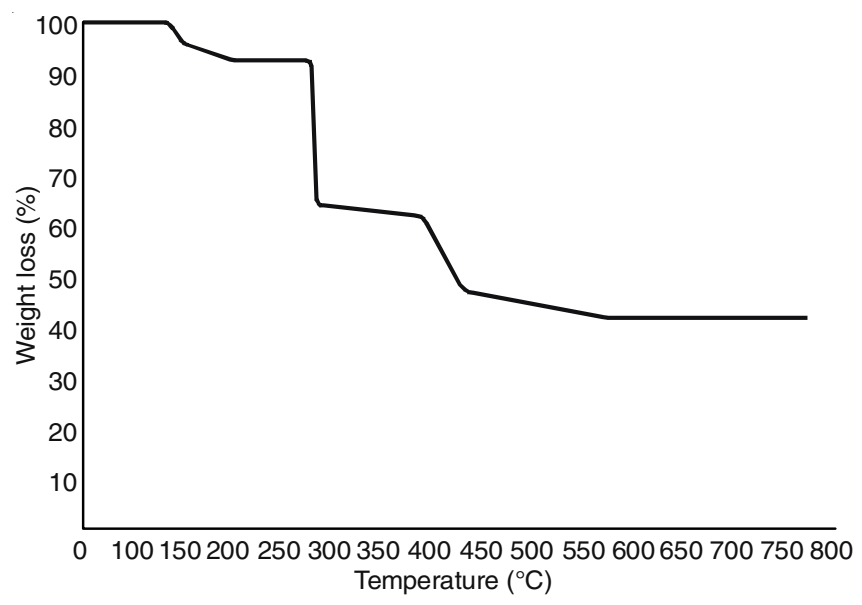

Fig. 5. TGA curve of $\left[\mathrm{ML}_{2}\left(\mathrm{H}_{2} \mathrm{O}\right)_{2}\right]$

In case of $\left[\mathrm{ML}_{2}(\mathrm{py})_{2}\right]$ complexes, the decomposition occurs in three steps. The first weight loss of 20 to $23 \%$ (calculated value 20.33 to $23.33 \%$ ) occurs at $170{ }^{\circ} \mathrm{C}$ and ends at $215^{\circ} \mathrm{C}$. The second decomposition occurs between 265 to $390{ }^{\circ} \mathrm{C}$ with the weight loss of 37 to $37.8 \%$ (calculated value 37.7 to 38.22 $\%$ ) due to loss of $\mathrm{C}_{13} \mathrm{H}_{10} \mathrm{O}_{2}$ moiety. The rest part of the ligand gets decomposed between $450{ }^{\circ} \mathrm{C}$ to $560{ }^{\circ} \mathrm{C}$ with the weight loss of 24 to $25 \%$ (calculated value 25.0 to $25.62 \%$ ). The complexes $\left[\mathrm{ML}_{2}(\alpha \text {-pico })_{2}\right]$ also show the similar pattern of thermal decomposition (Fig. 6). Thus, it is clear from thermogravimetric analyses that water, pyridine and $\alpha$-picoline are attached to metal ion along axial position with slightly greater distance in respect of planer donar atoms.

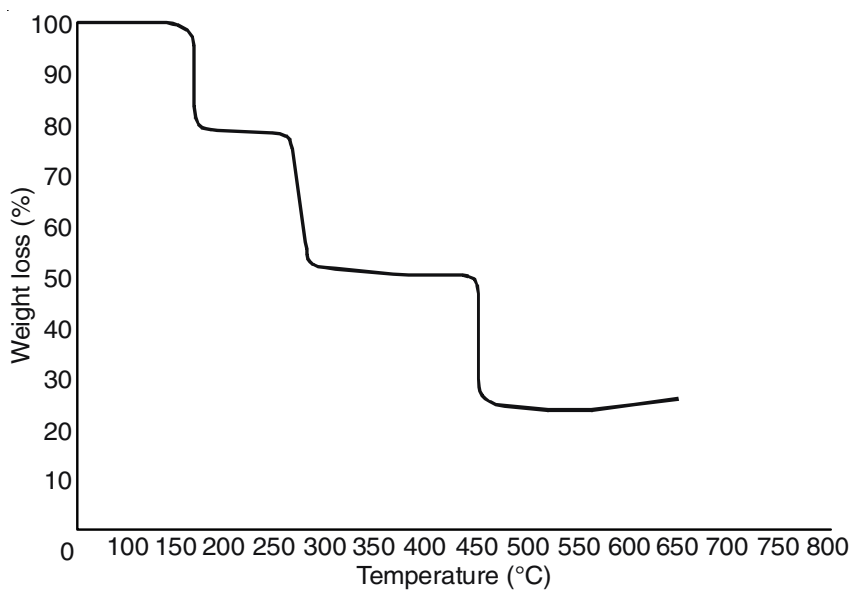

Fig. 6. TGA curve of $\left[\mathrm{ML}_{2}(\mathrm{Py})_{2}\right]$ and $\left[\mathrm{ML}_{2}(\alpha \text {-pico })_{2}\right]$

\section{Conclusion}

On the basis of IR spectral analyses of complexes in comparison to that of free ligand, 1-benzoyl-2-(2'-carboxylphenyl)iminopropane has been found to have acted as bidentate monoanionic ligand coordinated through deprotonated hydroxyl oxygen and azomethine nitrogen. The molar conductivity, magnetic moment and electronic results siggest the following tentative structure of the metal complexes.

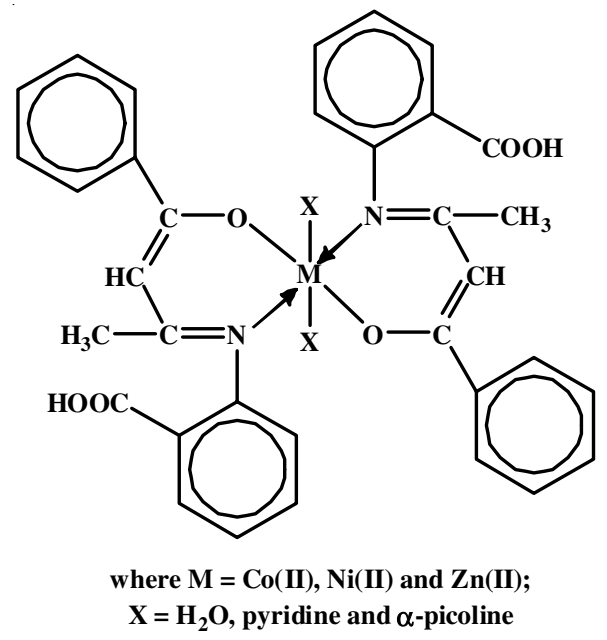

\section{CONFLICT OF INTEREST}

The authors declare that there is no conflict of interests regarding the publication of this article.

\section{REFERENCES}

1. P.B. Chakrawarty, J. Indian Chem. Soc., 78, 273 (2001).

2. S.J.S. Flora and V. Pachauri, Int. J. Environ. Res. Public Health, 7, 2745 (2010); https://doi.org/10.3390/ijerph7072745.

3. P.B. Chakrawarty, J. Sci. Ind. Res., 48, 529 (1989).

4. P.G. Ramappa, J. Indian Chem. Soc., 76, 235 (1999).

5. H. Sigel, Angew. Chem. Int. Ed. Engl., 14, 394 (1975); https://doi.org/10.1002/anie.197503941.

6. H. Sigel and B. Martin, Chem. Rev., 82, 385 (1982); https://doi.org/10.1021/cr00050a003.

7. J.E. Coleman and D.P. Giedroc, Met. Ions Biol. Syst., 25, 171 (1979).

8. G.N. Mukharjee and S. Basu, J. Indian Chem. Soc., 76, 288 (1999).

9. L. Mishra and V.K. Singh, J. Agric. Biol. Chem. Japan, 55, 1883 (1991); https://doi.org/10.1271/bbb1961.55.1883.

10. N. Nayak and P.G. Ramappa, Asian J. Chem., 7, 860 (1995).

11. P.B. Chakrawarty and R. Agarwal, Orient. J. Chem., 10, 119 (1994).

12. M.A. Ghandour, E. Abdul Kasim, A.H. Amrallah, N.A. Abdalla and O.A. Farghty, J. Indian Chem. Soc., 76, 480 (1999).

13. P. Vigato, S. Tamburini and L. Bertolo, Coord. Chem. Rev., 251, 1311 (2007); https://doi.org/10.1016/j.ccr.2006.11.016.

14. N.E. Borisova, M.D. Reshetova and Y.A. Ustynyuk, Chem. Rev., 107, 46 (2007); https://doi.org/10.1021/cr0683616.

15. K.C. Gupta and A.K. Sutar, Coord. Chem. Rev., 252, 1420 (2008); https://doi.org/10.1016/j.ccr.2007.09.005.

16. C.M. Che, S.C. Chan, F.H. Xiang, M.C.W. Chan, Y. Liu and Y. Wang, Chem. Commun., 1484 (2004); https://doi.org/10.1039/B402318H.

17. H.C. Lin, C.C. Huang, C.H. Shi, Y.H. Liao, C.C. Chen, Y.C. Lin and Y.H. Liu, Dalton Trans., 781 (2007); https://doi.org/10.1039/b615380a.

18. A.M. Abu-Dief and I.M.A. Mohamed, Beni-Suef Univ. J. Basic Appl. Sci., 4, 119 (2015); https://doi.org/10.1016/j.bjbas.2015.05.004.

19. T.M. Ross, S.M. Neville, D.S. Innes, D.R. Turner, B. Moubaraki and K.S. Murray, Dalton Trans., 39, 149 (2010); https://doi.org/10.1039/B913234A.

20. T.D. Pasatoiu, J.P. Sutter, A.M. Madalan, F.J.C. Fellah, C. Duhayon and M. Andruh, Inorg. Chem., 50, 5890 (2011); https://doi.org/10.1021/ic2004276.

21. E.N. Chygorin, O.V. Nesterova, J.A. Rusanova, V.N. Kokozay, V.V. Bon, R. Boèa and A. Ozarowski, Inorg. Chem., 51, 386 (2012); https://doi.org/10.1021/ic2017962. 
22. M. Sutradhar, L.M. Carrella and E. Rentschler, Polyhedron, 38, 297 (2012); https://doi.org/10.1016/j.poly.2012.03.021.

23. Y. Wang, Z.Y. Yang and B.D. Wang, Transition Met. Chem., 30, 879 (2005); https://doi.org/10.1007/s11243-005-6166-9.

24. A.A.A. Abu-Hussen and A.A.A. Emara, J. Coord. Chem., 57, 973 (2004); https://doi.org/10.1080/00958970412331272412.

25. J. Chakraborty, B. Samanta, G. Pilet and S. Mitra, J. Struct. Chem., 17, 585 (2006) https://doi.org/10.1007/s11224-006-9076-3.

26. I. Ramaswami and S. Ramaswami, J. Indian Chem. Soc., 91, 1877 (2014).

27. B.B. Mahapatra, A.K. Sarangi and R.R. Mishra, J. Indian Chem. Soc., 93, 9 (2016).

28. K. Nakanshi, Infrared Absorption Spectroscopy, Holden-Day. Inc. San. Francisco and Nakado Company Limited, Tokyo, 2nd printing, p. 30 (1964).

29. M. Oki and H. Iwamura, Bull. Chem. Soc. Jpn., 34, 1395 (1961); https://doi.org/10.1246/bcsj.34.1395.

30. K.K. Gangu, A. Vankayala, A.S. Dadhich and M.S. Babu, J. Indian Chem. Soc., 93, 169 (2016).

31. S.K. Gharad and B.N. Barad, J. Indian Chem. Soc., 93, 223 (2016).

32. R.S. Bhaskar, M.G. Salunkhe, A.R. Yaul and A.S. Aswar, J. Indian Chem. Soc., 93, 419 (2016).

33. P. Majumdar, J. Indian Chem. Soc., 93, 19 (2016).

34. W. Kaim, Coord. Chem. Rev, 255, 2503 (2011); https://doi.org/10.1016/j.ccr.2011.01.014.

35. D.T. Schühle, J.A. Peters and J. Schatz, Coord. Chem. Rev., 255, 2727 (2011); https://doi.org/10.1016/j.ccr.2011.04.005.

36. A.K. Singh, S.P. Sinha, V. Kumar, S.S. Rai and S. Sharma, Asian J. Chem., 23, 4347 (2011).

37. N. Bandyopadhyay, L. Lu, M. Zhu, R. Bhattahachrya and J.P. Naskar, J. Indian Chem. Soc., 92, 15 (2015)

38. K. Binnemans, Y.G. Galyametdinov, R. Van Deun, D.W. Bruce, S.R. Collinson, A.P. Polishchuk, I. Bikchantaev, W. Haase, A.V. Prosvirin, L. Tinchurina, I. Litvinov, A. Gubajdullin, A. Rakhmatullin, K. Uytterhoeven and L. Van Meervelt, J. Am. Chem. Soc., 122, 4335 (2000); https://doi.org/10.1021/ja993351q.
39. U. Panda, D. Mallik and C. Sinha, J. Indian Chem. Soc., 93, 705 (2016).

40. R. Ranjan, R. Rani, S.S. Singh, A. Singh and S. Sharma, Asian J. Chem., 22, 7580 (2010)

41. M. Bala and L.K. Mishra, J. Indian Chem. Soc., 91, 143 (2014).

42. M.A. Hitchman, Inorg. Chem., 11, 2387 (1972); https://doi.org/10.1021/ic50116a019.

43. J.A. Creighton, M.G. Albrecht, R.E. Hester and J.A.D. Matthew, Chem. Phys. Lett., 55, 55 (1978); https://doi.org/10.1016/0009-2614(78)85131-8.

44. A. Joseph, B. Joseph and B. Narayana, J. Indian Chem. Soc., 85, 479 (2008)

45. I.P. Khullar and U. Agarwal, Can. J. Chem., 53, 1165 (1975); https://doi.org/10.1139/v75-161.

46. D. Kumar, J. Kumar, S. Chadha and S. Shymal, J. Indian Chem. Soc., 91, 185 (2014)

47. D. Kumar and Neelam, J. Indian Chem. Soc., 92, 319 (2015).

48. A. Rastogi and A.K. Anurag Pandey, J. Indian Chem. Soc., 87, 1053 (2010).

49. R.L. Carlin and E. Weissberger, Inorg. Chem., 3, 611 (1964); https://doi.org/10.1021/ic50014a044.

50. A.B.P. Lever, I.M. Walker and P.J. McCarthy, Spectrosc. Lett., 12, 739 (1979); https://doi.org/10.1080/00387017908069200.

51. R. Ranjan, S. Suraiya, V. Kumar and S. Sharma, Proceedings of DAEBRNS, International Symposium on Material Chemistry, BARC, Mumbai, pp. 494-497 (2006).

52. R. Ranjan, N. Sinha, S. Kumar, C.M. Chandra and S. Sharma, IRA Int. J. Appl. Sci. (Faisalabad), 7, 34 (2017); https://doi.org/10.21013/jas.v7.n1.p3.

53. N.H. Butters, S.M. Mohaned, A.A. Sabah and E.A. Abdalarazaq, Asian J. Chem., 25, 4856 (2013); https://doi.org/10.14233/ajchem.2013.14125.

54. B. Krishnan and S.A. Iqbal, J. Indian Chem. Soc., 91, 367 (2014).

55. S. Karim and S. Saffrian, J. Indian Chem. Soc., 92, 325 (2015).

56. A.V. Nikolayev, V.A. Logvineko and L.I. Mychina, Thermal Analysis, Academic Press: New York, vol. 2, p. 779 (1969). 